\title{
GENDER SUFFIX PARADIGMS CORRELATION IN ENGLISH, RUSSIAN, AND UKRAINIAN
}

\begin{abstract}
Summary. The word-formation category of femininity and masculinity and their overlaping are the problems of the universal grammar.This paper is a study of the common gender nouns with the agent-meaning suffixes in English and their Russian and Ukrainian correspondences, which create the nominations of the doer of an action. The paper presents a contrastive research into the combinatorial potential of the agentive suffixes in English, Russian, and Ukrainian and their common and distinctive features. A set of agentive suffixes of the English derivative nouns does not coincide with a set of agentive suffixes of the Russian and Ukrainian derivatie nouns (see Classen 1919, Booij, 1995, Jovanovic 2013, Hill 2014, Crystal, 2019). Corbett (1999) refers Grammatical Gender to Agreement Classes: Feminine, Masculine, Neuter, and Natural. The different terms like Masculine, Feminine, and Neuter genders are merely the products of different linguistic traditions and schools.

Most Englsh suffixes are gender neutral, i.e. all of them may be used to form masculine and feminine performer nouns. There is no separate, sex-indefinite class for reference to human beings in general. The neuter gender, which theoretically could have taken over such a function, has lost the capacity to classify animate nouns almost completely The typical English agentive derivative tmploys a free base of simple morphological structure, formed from a bare infinitive. It's sometimes useful to have a feminine version of a masculine noun, since English overall is gender-neutral, unlike many other languages, where each noun has a gender or masculine and feminine forms. The use of feminine suffixes has declined and has become less acceptable due to the influence of feminism in the Englishspeaking world. Kazaki (2013) presents the data which proves that several feminine suffixes such as -ette, -trix are of limited use, while -ess is the most common form among feminine suffixes, though a reduction in the use of -ess forms over time is apparent As opposed to some other languages, English agentive suffixes are devoid of gender distinctions.
\end{abstract}

Key words: suffix, nomination, feminine, musculine, semantics, functions.

Preliminaries. It is a truth universally acknowledged that natural languages do not exhibit an absolute one-to-one correspondence between meaning and form. The noun grammatical category of gender - Masculine, Feminine, and Neuter - rarely coincides with the biologicl sex of the referents. Brown ponits to the relation of grammatical gender with the natural one: "connected with gender, this term originally meant 'type' or 'class' but in European linguistics usage was narrowed to that of natural gender, 'male' vs 'female', plus 'neuter' (neither male nor female). Nouns in many Indo-European languages are divided into classes which have a basis in natural gender"
[5, p.163]. Corbett refers Grammatical Gender to Agreement Classes: Feminine, Masculine, Neuter, and Natural [8]. While these Agreement Patterns are governed by Natural Gender where it exists in a head noun where itdoes not, Agreement defaults to the Declension Class of that noun [3, p. 59].

An agent noun is a derived noun whose general meaning is "person who usually / typically does". Thus it is characterized by the feature [+ Human], irrespective of the fact that the person involved actually performs an action (swimmer "a person who swims"), carries on a profession (carpenter "a person who builds or repairs wooden structures"), or adheres to a certain ideology or group, e.g., a socialist "a person who supports or follows "socialist party." A set of agentive suffixes of the English derivative nouns does not coincide with a set of agentive suffixes of the Russian and Ukrainian derivatie nouns [6, p. 163; cf 9; 4, p. 503; 16, p. $85 ; 18$, p. 167]. The defining characteristic of gender is agreement, like in Russian and Ukrainian, a language has a gender system only if noun phrases headed by nouns of different types control different agreements with adjectives or verbs. The evidence that nouns have gender in the English language is more extralinguistic than intralinguiatics. The different terms like Masculine, Feminine, and Neuter genders are merely the products of different linguistic traditions and schools.

This paper presents a research of the frequent agentive suffixes of English derivative nouns their Russian and Ukrainian correspondences. The main purpose of the research undertaken is to investigate the characteristics of the bases involved in a derivative relationship with agentive suffixes and establish the potential points of similarity and / or distinction between the three languages.

Discussion. The concept of gender means that there are three different sets of noun types, and their modifiers (adjectives) and determiners (articles and demonstratives) have different forms accordingly. Nofal admits that "the sets of noun types are masculine, feminine, and neuter, but there is not any absolute relation between these conventional labels for the word categories and the objects, persons or animals that the nouns refer to" [22, p. 205]. The lack of one-to-one correspondence between form and meaning is referred to as 'morphological asymmetry' by Beard $(1984,1995)$ who says that "recent work son grammatical categories define Gender as an Agreement class, and a close examinationof the Slavonic languages, however, reveals that Natural ender, Agreement, and Declension Class all must be maintained and distinguished [2, p. 56].

More than one third of all commonly used nouns are feminine, most of them belong to the so-called - $\overline{0}$ declension (corresponding to the à stems. In the nominative singular, these have $-\mathrm{u}$ (sometimes -0 ) 
after a short syllable, as in lufu (love) and no ending at all after a long syllable, as in lār (learning) and wūnd (wound) [22, p. 206]. This asymmetry has led several grammarians to disconnect form and meaning in morphology, for example, Beard distinguishes between derivation rules and affixation rules [3, p. 639-640]. The gender studies and correlation of Mascular/Common nouns with Feminine nouns in the English Community pose, primarily, socio-linguistic problem where there is a strive to avoid a feminine marker. On the contrary, feminizing the Masculine/Common nouns is gathering its pace in cross-cultural linguistics, namely, in Ukrainian [20, p. 238fl].

Throughout the historical changes English obviously lost the case marking system, and it was more or less completely lost by the end of the Middle English period [11, p. 6-7]. The category of the doer of action is on the crossroads of morphology, lexicology,and semantics. The names of the performers of the action by the nature of their occupations and mode of activity, the genus of their profession is one of the richest word-forming categories both in terms of the number of tokens and in the variety of wordforming types within the word-forming category of a person. The grammatical category of English gender nouns seased to be marked due the reduction and loss of the stressed vowels in the final position [6, p. 97]. Some authors stress that the origin of gender is purely formal: some suffixes of sex-diff erentiable nouns acted as attractors, and created the genders in a purely formal, non-semantic way (Brugmann, 1899). This leaves the question of what caused sex-differentiable nouns open. Another possible answer is that in some languages the initially semantic neuter gender was lost, and the void was filled by masculine and feminine genders being assigned to previously neuter nouns.

Corpus analysis. The research is based on the corpus of animate agent noun derivatives functioning in English, Russian, and Ukrainian to differentiate common, masculine, and feminine genders that may result in the typology of gender means of expression. Models of the mechanisms by which nouns are allotted to genders are called 'assignment systems.' Assignment may involve two sorts of information about the noun: its meaning and its form [8]. We are planning an inquiry into the general qualities of the most frequent agentive suffixes in English and Russian and Ukrainian.

Even though agentive suffixes exist in the typologically different languages, their properties may considerably differ, particularly in terms of volume, type, productivity, combinatory power or grammatical implications. The problem of the combinatorial properties of derivational suffixes has been described by Plag and Baayen as "one of the most intricate problems in English morphology" [23, p. 109-110]. The main purpose of the research undertaken is to investigate the characteristics of the bases involved in a derivative relationship with agentive suffixes and establish the potential points of similarity and / or difference between the three languages. Due to the span of the research, the focus of the attention is exclusively nomina agentis in the three languages including other related derivational phenomena, such as nomina professionalis, names of practitioners, or professionals in different fields.

English agentive suffixes of the masculine or common gender

Agentive suffixes are usually said to be post-positioned affixal morphemes used to produce derivatives the meaning of which refers to "a person who has to do with what is indicated by the base". From a different perspective, agentive suffixes are, strictly speaking, used to derive nouns the semantic role of which is that of an AGENT. As it has been already determined by Fillmore (1968) that agentive suffixes may be appended to different types of bases. The most typical base would be a verb base, as the verbs designate actions, states or events. However, nouns may serve as bases when the outcome is nomina professionalis, both conversion-nouns and ordinary nouns. When some of these suffixes are added to adjectival bases, the derivatives are not strictly agentive nouns [13].

Foundalis writes that learners of languages that employ "natural gender", such as English, notice the close correlation between gender and sex [14, p. 4] it makes more sense in the mind of a native speaker of a natural gender language (such as English), where "male" - "masculine" and "female" - "feminine" nearly coincide conceptually. For a native speaker of a formal gender language this explanation seems to be simplistically projecting the natural-gender speaker's view of the world onto everyone else.

\section{English agent-meaning suffixes (common or masculine} genders)

The suffix - er of the Germanic origin produced the most nouns in the period $1500-1700$. It is extremely productive with vebal nouns but also yields denominal nouns (tinner, paddler) in Early Modern English. In the late $15^{\text {th }}$ century it begins to produce agent nouns and further used to derive nouns meaning an inhabitant of. $[17$, p. $392-393)$. Nouns ending in -er, and have a meaning roughly equivalent to 'doer of $\mathrm{X}$ ', where ' $\mathrm{X}$ ' is the action denoted by that part of the word that is not -er. Historically, the suffix -er denoted individuals of male gender, but the feature is not sustained. The noun with the suffix - er is frequently polysemous as it may have all three semantic components and the context can reveal the component encoded by the authorchoice of the desired value is determined by the context.

The suffix - er may be combined with vervb base denoting the type of activity; the verb bases denoting the process of utterance. However, certain noun-based derivatives may pose a problem as it is unclear whether the base is a noun or a conversion-verb, see box-er, may well have been derived from the verb to box. The stems with the suffix can have a feminine counterpart - ress, though there can be a genderless equivalent used, cf:: police officer instead of policeman/policewoman.

The suffix -ar is considered to be an alteration of -er or -or, occurring in a handful of instances like beggar, liar and padlar, and unlike its alternatives, it is unproductive. The suffix -or unlikeer, which combines with bases of different origins the suffix - or produces derivatives from Rom - or doctor, professor are used for both masculine and neuter. Sometimes the traditionally-male word is used for all genders: for example, actor for both male and female, instead of actor for male and actress for female. The suffix - aster / -estre borrowed from Latin became a productive masculine agentive suffix in the older Germanic languages, gradually displacing various native agentive suffixes.

Despite some assertions to the contrary, OE -estre can be shown to have been a feminine agentive suffix of Germanic origin that was also applied to certain feminine animal names. During the Old English period, a pattern obtained whereby masculine agent nouns were frequently derived using -ere (<PGmc. *-ārjaz), while the corresponding feminine agent nouns used -estre [15, p. 130]. This system died out in English as -er was increasingly used to form agent nouns of both genders. 
The - aster is generally a pejorative suffix denoting resemblance was common a couple hundred years ago but is rare today; the only well-known surviving instance is poetaster, a word describing an inferior poet, rhymester, youngster, songster. Some -er occupations (used to) become -ster, e.g. baxter $=$ female baker, and brewster = female brewer (of ale). The French suffix -ant/-ent which can be found predominantly in adaptations of boirrowings from French, reveals two semantic components in the lexical meaning derivatives, "a person that performs the action in the base", an agent, as in as in assistant, inhabitant, president, protestant, suppliant and "a material agent that does something expressed by the base", as disinfectant.

The suffix -ee of Latin and French origin primarily used to designate a person who undergoes a certain action, or presents an indirect object of the verb in the base, it also may have agentive implications, as in atend-ee "someone who attends or is present", returnee "someone who returned", but surrender-ee is "someone to whom a surrender is made". The nominations do not differentiate between Masculine and Feminine. The suffix -ee is the counterpart in legal matters to the Latinate suffix -or, appearing in pairs such as less-or vs. less-ee or grant-or vs. grant-ee, etc.

The French-based suffix -eer became productive in the 15-th century more significant in derivation of professional names, can also be employed in the agentive noun derivation, as nouns such as commandeer, mutineer, racketeer can confirm. Another suffix that could be considered within this group is the suffix -ist added to noun bases to produce nouns signaling professionals, adherents or generally performers of certain actions as copy-ist, typ-ist. However, when -ist is affixed to verbal bases to form agentive nouns, the productivity is much more limited. Of around 700 derivatives in -ist, only $1 \%$ would be those based on verbs, such as computist, guitarist, etc. The suffix -ian produces derivatives from noun bases: musician, beautician,. The suffix -ian as well as the suffix -ist actualize the component of a specialist or expert: grammarian, logician, etc.

\section{English agentive suffixes of the feminine gender}

Fowler (1926) once discussed the use of the nouns with feminine suffixes and predicted that the day would come when feminine forms for vocation-words were a special need of the future, with the coming expansion of vocations open to women. Contrary to Fowler's prediction, the use of feminine suffixes has declined and has become less acceptable due to the influence of feminism. Kazaki's data proves that sveral feminine suffixes such as -ette, -trix, are of limited use, while - ess is the most common form among feminine suffixes, though a reduction in the use of -ess forms over time is apparent [19, p. 185; cf 10].

The -ess agent nouns, form female counterparts to masculine agent nouns, but in the case of sorceress, the female counterpart can in some cases be attested earlier than the masculine form (OED). The suffix -ster (Old English -istre from Proto-Germanic *-istrijon, feminine agent suffix used as the equivalent of masculine -ere). Also used in Middle English to form nouns of action (meaning "a person who ...") without regard for gender: chorister, spinster probably carries an originally female ending). In Middle English many words in -esse were adopted from French; such as, countess, duchess, mistress, and princess [1, p. 343]. The most common feminine suffix in English is "-tress, for instance, auditress "female hearer or listener," ancestress (s) (noun), ancestresses (pl) "a woman from whom a person is descended, benefactress "a woman, who is inclined to participate in activities which support individuals or institutions," adulteress ("a woman who commits immoral relations with a man who is not her husband".

The suffix -stress is considered to be a dead one: seamstress. The suffix - trix: Webster's New World College Dictionary says, is the "suffix forming feminine nouns of agency". The masculine suffix is "or". Thus, executor / executrix, administratrix, aviatrix, directrix, dominatrix, executrix, and testatrix, dominatrix. The Oxford English Dictionary traces the "-trix" suffix to the 15th century, from Medieval Latin. A few others, like "directrice," use an alternate spelling of "-trix." The suffix -ine: English does not have a dearth of ways to let you know whether a man or woman is the subject. Some, like fiancé / fiancée and "comedian / comedienne," are adopted directly from other languages.

The suffix -ette: English nouns in which the suffix -ette designates a feminine role or identity have been perceived by many people as implying inferiority or insignificance: bachelorett.; drum majorette, usherette. Of these terms, only drum majorette - or sometimes just majorette - is still widely used, usually applied to one of a group of young women who perform baton twirling with a marching band. A woman or man who actually leads a band is a drum major. Baton twirler is often used instead of (drum) majorette. Farmer, suffragist, and usher are applied to both men and women, thus avoiding any trivializing effect of the -ETTE ending. Cf::farmer $\rightarrow$ farmerette, usher $\rightarrow$ usherette; major vs majorette. The suffix -euse, borrowed from French, masseur vs masseuse.

The Russian verbal derivatives with the agentive suffix of the masculine or common genders

As in many other European languages, Doleschal and Schmid (1999) write, in Russian nouns and pronouns are divided into three gender classes. There are three gender classes: feminine, masculine and neuter. Nouns denoting persons normally belong to the masculine or feminine gender, i.e. nouns denoting male human beings are masculine, and nouns denoting female human beings are feminine (Švedova, 1980). There is no separate, sex-indefinite, class for reference to human beings in general. The neuter gender, which theoretically could take over such a function, has lost the capacity to classify animate nouns almost completely [12, p. 253, 7]. The suffix -аг(a): бродяга, работяга; -ак/ -ак(а): вожак, гуляка; -ант: консультант, оккупант; -арь: звонарь, пахарь;-атай: гламатай; -атор: организатор; -ач: рвач, ткач; -ец: бореи, твореи; -ник/ -еник/ -енник: работник, проводник,; -ок/ -ток: едок, игрок; - -ёр /-ор: гравёр, инструктор; -с(а): плакса; -тель/-атель/-итель: испытатель, писатель; -ун: бегун, лгун, опекун; --х(а) / -ох(а): пряха, выпивоха; -ц(а)/ -йц(а) / -ойц(а): пропойща, убийца; -щик/-чик/-льщик: прищепщиик, переводчик; -ыш: оборвыш, подкидыми.

\section{Russian feminine agentive nouns and their derivative} suffixes

Russian feminine agentive nouns are formed with the help of 25 suffixes. The suffixes form feminine nouns from verbs actualizing a semantic component "carrier (performer) of an action or state": -лК (а): гадать - гадалка, сидеть - сиделка (медсестра); -ея: иить швея, ворожить - ворожея; -ин(я)/-ын(я):рабыня, героиня; -ис(а)/ -есс(а): актриса, директриса; -их(а): повариха, портниха, -иц(а): императрища, мастерища;-- -j(а): гостья, сватья;- -к(а)/ -овк(а)/ -анк(а)/ енк(а): гречанка, плутовка, монашенка.

The Russian suffixes of the Feminine gender are linked to the derivatives with the Masculine agentive suffixes: Noun base + 
musculine agentive suffix (-ник) + feminine suffix $(-$ ия): и т. д. Noun base + musculine agentive suffix (-чик/-щик) + feminine suffix (-чица/-шиц(а): (а) переписчик $\rightarrow$ к переписчища; (б) натурщик $\rightarrow$ натурщища. Noun base + musculine agentive suffix (-льщик) + feminine suffix (-льщица): рисовальщик $\rightarrow$ рисовальщица. Noun base + musculine agentive suffix (-тель) + feminine suffix (-льница): житель - жительница. Obviously, the vast majority of these words are formed by the Masculine agentive noun and the Femine noun suffixes. But, of course, it is possible to directly produce the names of female persons from the verb stem using the feminine suffix. Russian Noun base + Masculine (Common) -ент /ист $+\rightarrow$ Feminine suffix -к(а) студент - студентка, артист - артистка. Noun base + Masculine (Common) (-ец-/ель/арь) + $\rightarrow$ Feminine suffix (-ица/ша.-иха/-иня/-есс): -иц (а): красавец - красавица, певеи - певица; -ниц (а): учитель-учительница; -ш(а): музыкант-музыкантша; -их (а): повар - повариха; -ин (я): герой - героиня; -есс (а): прини - принщесса. Cf the Engliss suffixes of the Faminine gender are linked to the derivatives with the Masculine agentive suffixes: Noun base + Masculine /-Common suffix (-or/er/-0): Feminine suffix (-ess, -ine, -trix): author - authoress; baron - baroness; count-countess; giant - giantess; heir-heiress; host-hostess; poetpoetess. The following Feminine nouns are formed by substituting the Masculine or Common gender or, -er $\rightarrow$-es: (a)actor -actress; emperor - emperess; enchanter - enchantress; waiter - waitress; master - mistress; sorcerer - sorceress; and by adding the suffix -ess to the Masculine noun base: duke - duchess; prince - princess.

Ukrainian agent nouns suffixes: masculine and feminine

They distinguish between Masculine and Feminine genders: Ukrainian noun base + Masculine suffix -як/ -ар/ -ач/ -н-ик/-ist + Feminine suffix, for instance: -як, $\mathrm{m} \rightarrow$-ячка, $\mathrm{f}$ :моряк,m морячка f: -ap, m $\rightarrow$-рка, f: лікар - лікарка; - ач, m $\rightarrow$-ач-ка, $\mathrm{f:}$ викладач - викладачка; -н-ик $\mathrm{m} \rightarrow$-н-иця, f: учасник учасниця; - ик, m $\rightarrow$ иця, f: художник - художниця; -ist, $m \rightarrow$ -іст-ка, f: кераміст - керамістка. The most frequent Feminine suffix in the Slavonic languages $-k a$, has also the diminutive and instrumental functions [16, p. 16]. According to Russian and Ukrainian grammars the suffix $-\mathrm{K}(\mathrm{a})$ is attached to motiveless nouns of masculine gender [24, p. 503; see also 21].

Findings and perspectives. Various terms like Masculine, Feminine, and Neuter genders are merely the products of different linguistic traditions and schools. Most Englsh suffixes are gender neutral, i.e. all of them may be used to form masculine and feminine performer nouns. There is no separate, sex-indefinite class for reference to human beings in general. The neuter gender, which theoretically could have taken over such a function, has lost its capacity to classify animate nouns almost completely The typical English agentive derivative tmploys a free base of simple morphological structure, formed from a bare infinitive.

The English feminine suffixes must be used judiciously. Although some individuals are unconcerned about morphological forms that distinguish men from women, others see such distinctions as unnecessary and perhaps even demeaning to women, though in Ukrainian they become popular iparticular in mass media. The Ukkrainian suffix-к(a) is the most popular in feminist media space for several reasons: (i) the existence of a large number of feminitives formed by derivational model that emphasizes the "naturalness" of Russian / Ukrainian language forming feminitives-neologisms; (ii) lack of restrictions (formal, semantic, stylistic), affecting ability of morphemes to join different types of bases; (iii) regularity of suffix -к(a) in Slavonic languages (see Ukrainian: лікарка, авторка, but Russian врач, доктор, автор).

\section{References:}

1. Barnhart Robert K. (ed.) The Barnhart Dictionary of Etymology. Bronxville, New York : The H.W. Wilson Company, 1995. 916 p.

2. Baugh A. and Thomas C. A History of the English Language. Upper Saddle River, N.J. : Prentice Hall, 1993. xiv, 447 p.

3. Beard Robert. The Gender-animacy hypothesis. Journal of Slavic Linguistics. 1995. Vol. 3(1). P. 59-96.

4. Booij Geert E. Form and meaning in morphology: the case of Dutch agent nouns. Linguistics. 1986. Vol. 24. P. 503-517.

5. Brown Keith. Encyclopedia of Language and Linguistics. Elsevier Science, 2006. 9000 p.

6. Classen E. On the Origin of Natural Gender in Middle English. Modern Language Review. 1919. Vol. 14. P. 97-103.

7. Corbett Greville G. Gender in Russian Russian Linguistics. 1982. Vol. 6, No. 2. P. 197-232.

8. Corbett Greville G. Gender (2nd ed.). Cambridge : CUP, 1999. 382 p.

9. Crystal D. The Cambridge Encyclopaedia of the English. Cambridge: C UP, 2019. 518 p.

10.CurzanA. Gender shifts in the history of English. Cambridge: CUP 1999. 220 p.

11.Doleberg Florian. Gender Change from Old to Middle English. Selected Papers from the Sixteenth International Conference on English Historical Linguistics (ICEHL 16), Pécs, 23-27 August 2010, 2012.

12.Doleschal Ursula, Schmid Sonja. Russian. Doing gender in Russian. / Ed. Hadumod Bussmann and Marlis Hellinger. Gender across languages. An International Handbook. Amsterdam. Dordrecht: Benjamins, 2001. P. 253-282.

13.Fillmore C.J. The Case for Case. / Ed. E. Bach and R.T. Harms. Universals in Linguistic Theory. N.Y. : Holt, Rinehart, and Winston 1968. P. 1-88.

14.Foundalis H.E. Evolution of Gender in I-E languages. Proceedings of the 24-th Annual Conference of the Cognitive Science Society. Fairfax, 2002. P. 4-6.

15.Gąsiorowski Piotr. Cherchez la femme: Two Germanic suffixes, one etymology. Folia Linguistica Historica. 2017. Vol. 38. P. 125-147.

16.Hill Peter. Sex and gender in Croatian and other languages. Croatian Studies Review. 2014. Vol. 10. P. 85-103.

17.Hogg R.M. et al. The Cambridge history of the English language. Vol. 3. Cambridge : CUP 1992. $796 \mathrm{p}$.

18.Jovanović V.Ž. Combinatorial restrictions of agentive suffixes in English and Serbian. / Ed. Snežana Gududrić. Filozofski fakultet Univerzitet u Novom Sadu, 2013. P. 167-180.

19.Kazaki T. Feminine Suffixes in English. Kwansei Gakun University, 2013.

20.Luschützky H.C. \& Rainer F. Agent-noun polysemy in a cross-linguistic perspective. STUF-Language Typology. Universals Sprachtypologie und Universalienforschung. 2011. Vol. 64(4). P. 287-338.

21.Mykhaylenko Valery. Feminizing the common gender in rendering from English into Ukrainian, 2019 (in print).

22. Nofal K.H. Nouns and Adjectives of Old English and Modern Standard Arabic. A Comparative Study. International Journal of Humanities and Social Science Vol. 1 No. 18. P. 203-225. 
23.Plag I., Baayen H. Suffix ordering and morphological processing. Language. 2009. Vol. 85(1). P. 109-152.

24.Rojavin Marina. The Semantic category of gender in Russian and Ukrainian. The Slavic and East European Journal. 2010. Vol. 54. No. 3. P. 503-526.

Михайленко В. Кореляція парадигм родових суфіксів в англійській, російській та украӥнській мовах

Анотація. У статті представлено дослідження парадигм англійськоих, російських та українських суфіксів агентивних суфіксівта, які утворюють номінативний простір діяча. У фокусі дослідження - вивчення поширених родових іменників з суфіксами на позначення агента дії - суфіксальних парадигм в англійській, російській та українській мовах.

Стаття присвячена контрастивному аналізу комбінаторного потенціалу агентивних суфіксів в англійській, російській та українській мовах та їх спільних і відмінних особливостей. У більшості індо-європейських мов, наприклад російській та українській, іменники та особові займенники вирізняють три граматичні родові класи (Шведова, 1980). В англійській мові не існує окремого, «невизначеного» роду іменників на позначення статі людини (Doleschal and Schmid, 1999), а середній род, який теоретично міг би виконувати зазначену функцію, втратив майже повністю свою здатність класифікувати іменники на позначення «живої істоти».
Типовий англійський агентивний дериватив має просту морфологічну основу й утворюється від інфінітивної форми дієслова. Безумовно, у мові могли б бути іменники жіночого роду для протиставлення іменникам чоловічого роду, проте англійська мова на противагу іншим індо-європейським мовам, де кожен іменник має три родові форми, - гендерно нейтральна.

Англійські жіночі суфікси не часто вживаються у сучасному дискурсі: одні мовці відносятья нейтрально до їх вирізнення, інші вважають такі відмінності непотрібними та, можливо, навіть принизливими відносно жінок, проте, в українській мові вони стають популярними, зокрема, у мові 3МІ.

Суфікс -к(а) є частотним у слов'янському феміністичному медіапросторі 3 кількох причин: 1) існування значної кількості фемінітивів, утворених дериваційною моделлю, що підкреслює «природність» російської/українськоїмови,щоформуєфемініти-неологізми; 2) відсутність обмежень (формальних, семантичних, стилістичних), що впливають на здатність морфем приєднуватися до різних типів основ; 3) регулярність суфікса -к(а), наприклад, в українській: лікарка, авторка, мністерка, але в російській - врач, доктор, автор, министр.

Ключові слова: суфікс, номінація, жіночий, чоловічий, семантика, функція. 